\title{
Direct Costs of Opioid Abuse in an Insured Population in the United States
}

\author{
ALAN G. WHITE, PhD; HOWARD G. BIRNBAUM, PhD; MILENA N. MAREVA, BA; MAHAM DAHER, BA; \\ SUSAN VALLOW, RPh, MBA, MA; JEFF SCHEIN, DrPH, MPH; and NATHANIEL KATZ, MD
}

\begin{abstract}
OBJECTIVE: To (a) describe the demographics of opioid abusers; (b) compare the prevalence rates of selected comorbidities and the medical and drug utilization patterns of opioid abusers with patients from a control group, for the period from 1998 to 2002; and (c) calculate the mean annual per-patient total health care costs (e.g., inpatient, outpatient, emergency room, drug, other) from the perspective of a private payer.
\end{abstract}

METHODS: An administrative database of medical and pharmacy claims from 1998 to 2002 of 16 self-insured employer health plans with approximately 2 million lives was used to identify "opioid abusers"-patients with claims associated with ICD-9-CM (International Classification of Diseases, 9th Revision, Clinical Modification) codes for opioid abuse (304.0, 304.7, 305.5, and 965.0 [excluding 965.01]). A control group of nonabusers was selected using a matched sample (by age, gender, employment status, and census region) in a 3:1 ratio. Per-patient annual health care costs (mean total medical and drug costs) were measured in 2003 U.S. dollars. Multivariate regression techniques were also used to control for comorbidities and to compare costs with a benchmark of depressed patients.

RESULTS: 740 patients were identified as opioid abusers, a prevalence of 8 in 10,000 persons aged 12 to 64 years continuously enrolled in health care plans for whom 12 months of data were available for calculating costs. Opioid abusers, compared with nonabusers, had significantly higher prevalence rates for a number of specific comorbidities, including nonopioid poisoning, hepatitis $(A, B$, or $C)$, psychiatric illnesses, and pancreatitis, which were approximately $78,36,9$, and $21(P<0.01)$ times higher, respectively, compared with nonabusers. Opioid abusers also had higher levels of medical and prescription drug utilization. Almost $60 \%$ of opioid abusers had prescription drug claims for opioids compared with approximately $20 \%$ for nonabusers. Prevalence rates for hospital inpatient visits for opioid abusers were more than 12 times higher compared with nonabusers $(P<0.01)$.

Mean annual direct health care costs for opioid abusers were more than 8 times higher than for nonabusers $(\$ 15,884$ versus $\$ 1,830$, respectively, $P<0.01)$. Hospital inpatient and physician-outpatient costs accounted for $46 \%(\$ 7,239)$ and $31 \%(\$ 5,000)$ of opioid abusers' health care costs, compared with $17 \%(\$ 310)$ and $50 \%$ (\$906), respectively, for nonabusers. Mean drug costs for opioid abusers were more than 5 times higher than costs for nonabusers $(\$ 2,034$ vs. $\$ 386$, respectively, $P<0.01$ ), driven by higher drug utilization (including opioids) for opioid abusers. Even when controlling for comorbidities using a multivariate regression model of a matched control of depressed patients, the average health care costs of opioid abusers were 1.8 times higher than the average health care costs of depressed patients.

CONCLUSION: The high costs of opioid abuse were driven primarily by high prevalence rates of costly comorbidites and high utilization rates of medical services and prescription drugs.

KEYWORDS: Opioid abuse, Prevalence rates, Direct health care costs

J Manag Care Pharm. 2005;11(6):469-79

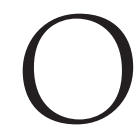
pioid abuse can impose substantial costs on society and to payers as well as to the users themselves. Although there has been some research on the overall costs of opioid abuse, few studies have undertaken systematic research of costs from the payer perspective and quantified the payer burden of opioid abuse. In this article, we analyzed the economic burden of opioid abuse (both prescription and nonprescription) from a private payer's perspective. The analysis focused on average per-patient direct health care costs (medical and drug) measured in 2003 United States dollars.

A number of studies have discussed the growing prevalence of opioid abuse in the United States. The National Household Survey on Drug Abuse (NHSDA) estimated that more than 6 million Americans used prescription pain relievers (e.g., oxycodone) for nonmedical purposes in 1999. By 2001, this number had increased to 8.4 million, approximately $4 \%$ of the U.S. population..$^{1-3}$ Findings from the National Survey on Drug Use and Health showed that nonmedical use of pain relievers among persons aged 12 years and older increased from 11.0 million to 11.7 million. ${ }^{4}$ Although these results are not directly comparable with those of the NHSDA, they indicate the growing prevalence of opioid abuse in the United States.

From 1999 to 2001, the number of patients admitted for the treatment of prescription opioid abuse increased from approximately 23,000 in 1999 to more than 38,000 in $2001 .^{5}$ Furthermore, the number of emergency room visits related to illegal drug use or nonmedical use of prescription drugs increased from approximately 250,000 in the latter half of 1997 to more than 325,000 in the latter half of $2001 .{ }^{6}$ The growing prevalence of drug and opioid abuse has caused an increase in

\section{Authors}

ALAN G. WHITE, PhD, is a vice president, HOWARD G. BIRNBAUM, PhD, is a vice president, MILENA N. MAREVA, BA, is a senior analyst, and MAHAM DAHER, BA, is a senior analyst, Analysis Group, Inc., Boston, Massachusetts; SUSAN VALLOW, RPh, MBA, MA, is associate director, primary care outcomes research, and JEFF SCHEIN, DrPH, MPH, is senior director, primary care outcomes research, Janssen Medical Affairs, L.L.C., Raritan, New Jersey; NATHANIEL KATZ, MD, is a vice president, medical affairs and pain research Inflexxion, Inc., Newton, Massachusetts.

AUTHOR CORRESPONDENCE: Alan G. White, PhD, Vice President, Analysis Group, Inc., 111 Huntington Ave., 10th Fl., Boston, MA 02199.

Tel: (617) 425-8217; Fax: (617) 425-8001; E-mail: awhite@analysisgroup.com

Copyright $\odot$ 2005, Academy of Managed Care Pharmacy. All rights reserved. 
government attention devoted to this problem; in 2001, the National Institute of Drug Abuse launched a public information campaign to educate patients, health care providers, and pharmacists regarding the potential dangers of prescription drug abuse. $^{7}$

Several researchers have attempted to quantify the costs associated with drug abuse, including opioid abuse. Without distinguishing between legal and illegal drug use, Harwood estimated that overall costs of drug abuse in 1998 were $\$ 97.7$ billion. ${ }^{8}$ His study focused on 3 major cost categories: health care, criminal justice, and workplace burden costs. The National Institutes of Health reported that, in 1998, the overall cost of drug abuse was $\$ 143.4$ billion, with $69 \%$ in lost productivity costs, $9 \%$ in health costs, and $22 \%$ in other costs such as criminal justice. ${ }^{9}$ There have also been a few studies that have focused on the costs associated with illicit drug abuse. ${ }^{10,11}$

Only one study was found that focused on prescription opioid abuse in particular. Birnbaum et al. found that the cost of prescription opioid abuse in the United States in 2001 was $\$ 9.2$ billion; approximately 30\% ( $\$ 2.8$ billion) was for health care, $50 \%$ ( $\$ 4.6$ billion) for lost productivity, and $20 \%$ ( $\$ 1.8$ billion) for criminal justice. ${ }^{12}$ Given the trends in increasing prevalence rates of prescription opioid abuse, its economic burden on society is very likely to escalate in the coming years. Furthermore, since the condition is likely to be underdiagnosed because of the associated stigma, the true burden is probably much greater.

This article focuses on the payer burden of opioid abuse by measuring the per-patient costs incurred by payers arising from all medical and pharmacy payments made for patients diagnosed with opioid abuse (i.e., related to opioid abuse and other comorbid conditions).

\section{Methods}

\section{Overview}

A group of patients with a diagnosis of opioid abuse was identified and randomly matched to a group of patients with no diagnoses of opioid abuse. Medical and pharmacy claims and eligibility data were used to compare the demographic characteristics, medical services and drug utilization, prevalence rates of selected comorbidities, and average annual direct health care (i.e., medical and drug) costs for patients for both groups. Patient samples were identified using ICD-9-CM (International Classification of Diseases, 9th Revision, Clinical Modification) codes for opioid abuse. The difference in costs between these 2 groups was used to calculate the excess burden of opioid abuse (i.e., the extent to which health care costs of opioid abusers were greater than those of nonabusers). Costs were measured as payer payments for services provided during a 12-month period for each patient during the years 1998-2002, and were adjusted to 2003 U.S. dollars using the medical consumer price subindex. Descriptive statistics for medical services and drug utilization, prevalence rates of selected comorbidities, and direct health care costs were compared for opioid abusers and nonabusers.

\section{Data}

The database contained deidentified administrative claims data for approximately 2 million insured members from 16 large employers for the period from 1998-2002. Together these employers had operations nationwide in a broad array of industries and job classifications. The data included all medical (e.g., hospital inpatient, physician office visits, etc.) as well as prescription drug claims for employees, spouses, and dependents. Prescription drug utilization was identified using both National Drug Codes (NDCs) for drug claims and Health Care Financing Administration Common Procedure Coding System (HCPCS) codes for medical claims where drugs were administered as part of a medical procedure. The data allowed for disaggregation of costs by place of service (e.g., hospital outpatient versus hospital inpatient). The data could therefore be used to compare the drivers of total payer costs across opioid abusers and nonabusers. The data also allowed comparison of medical and drug utilization and prevalence rates of selected prespecified comorbidities across opioid abusers and nonabusers. The prevalence rates were compared by calculating relative risk ratios (i.e., the ratio of the respective prevalence rates for opioid abusers to nonabusers), and statistical differences in prevalence rates were assessed using a chi-squared analysis. Differences in averages between the 2 samples were assessed using $t$ tests.

\section{Identification of Research Samples}

The patient research samples were identified as patients between the ages of 12 and 64 years who were continuously enrolled in health care plans for a 12-month period around the index date (defined below). Patients were identified as opioid abusers based on having at least 1 claim with at least 1 of the following 4 ICD-9-CM codes over the period 1998-2002:

304.0 opioid type dependence

304.7 combinations of opioid abuse with any other

305.5 opioid abuse

965.0 poisoning by opiates and related narcotics excluding poisoning by heroin (965.01)

The index date in this study was defined as the first observed date of diagnosis of opioid abuse. Patients were included if they had claims history for at least 6 months preindex date and 6 months postindex date. The index date was not necessarily the first date of diagnosis of opioid abuse, given the requirement of 6 months of medical claims history prior to the index date. If a patient was diagnosed with opioid abuse in February 1998, then this patient would not be included in the analysis, given that the patient would not have had at least 6 months of preindex date medical claims history (assuming there were no subsequent claims associated with opioid abuse). Patients were required to be continuously enrolled in health 
care plans during all 12 months of the study (i.e., the 6 months preindex and postindex date). The sample is likely to contain both prescription opioid abusers and nonprescription opioid abusers, since ICD-9-CM codes do not distinguish between the 2 types of opioid abuse.

It is worth noting that the term "opioid abuse" is a general term, used differently by different people in various contexts. In some cases, it means a less serious form of addiction, i.e., someone appears to be addicted but doesn't meet the full Diagnostic and Statistical Manual of Mental Disorders (DSM-IV) criteria for addiction (opioid dependence). ${ }^{7}$ In fact DSM-IV has specific criteria for opioid abuse. Definitions of prescription opioid abuse span a spectrum from episodic nonmedical use of a drug (Drug Enforcement Agency and National Institute for Drug Abuse) to nonmedical use resulting in harm (Institute of Medicine and Drug Abuse Warning Network) to very specific criteria such as those in DSM-IV ${ }^{7}$ In 2001, The American Academy of Pain Medicine issued recommendations for distinguishing between "physical dependence" and "addiction," where physical dependence referred to a condition characterized by withdrawal symptoms when one stops using opioids. By contrast, addiction "is characterized by behaviors that include one or more of the following: impaired control over drug use, compulsive use, continued use despite harm, and craving."13

Given the different uses of the term opioid abuse and the possibility for miscoding with the ICD-9-CM codes, we grouped all such ICD-9-CM codes that related to opioid abuse for the purposes of our cost calculations and analyses and labeled these patients "opioid abusers." However, recognizing that abuse and dependence may not necessarily be synonymous, we report some sensitivity analyses based on different cohorts defined by ICD-9-CM codes. These are discussed below.

A random sample was also drawn from the same overall patient population to serve as a comparison group. The same basic inclusion criteria imposed on the opioid abuse sample were also imposed on the matched sample: aged 12 to 64 years, continuously enrolled in a health care plan during all 12 months of the study period, and having at least 1 medical or prescription drug claim during that year. The random sample excluded patients with opioid abuse diagnoses and was matched with the opioid abuse sample by gender, age, employment status, and census geographic region on a 3:1 matching ratio.

An important feature of the analysis is that there was no "wash-out" period before or after claims associated with the ICD-9-CM codes for the opioid abusers in the study. Studies that impose a wash-out period before the first diagnosis and after the end of a "disease episode" are generally focused on capturing the cost of illness associated with the onset of the disease in question and its immediate treatment. In contrast, the goal of the current study was to capture a payer's typical direct medical cost burden for the average annual cost of illness for all patients diagnosed with opioid abuse who may have been in

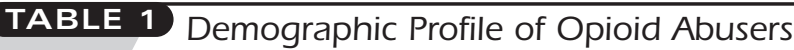 and Nonabusers, 1998-2002 (Patients Aged 12-64 Years)}

\begin{tabular}{l|c|c|c|c}
\hline \multirow{2}{*}{ Gender } & \multicolumn{2}{|c|}{ Opioid Abusers* $(\mathrm{N}=740)$} & \multicolumn{2}{c}{ Nonabusers* $(\mathrm{N}=2,220)$} \\
\cline { 2 - 5 } Male & $\mathbf{N}$ & $\%$ & $\mathrm{~N}$ & $\%$ \\
\cline { 2 - 5 } Female & 422 & 57.0 & 1,266 & 57.0 \\
\hline Age (years) & 318 & 43.0 & 954 & 43.0 \\
Mean & & & & \\
Median & 37.6 & & 37.4 & \\
Standard deviation & 39.0 & & 39.0 & \\
12-17 & 13.3 & & 13.5 & \\
18-34 & 56 & 7.6 & 168 & 7.6 \\
35-54 & 222 & 30.0 & 666 & 30.0 \\
55-64 & 389 & 52.6 & 1,167 & 52.6 \\
\hline Region & 73 & 9.9 & 219 & 9.9 \\
Midwest & & & & \\
Northeast & 105 & 14.2 & 315 & 14.2 \\
South & 153 & 20.7 & 459 & 20.7 \\
West & 388 & 52.4 & 1,164 & 52.4 \\
\hline
\end{tabular}

* Patients are required to have medical claims data 6 months preindex date and 6 months postindex date during which they are continuously enrolled in a health care plan. The index date here is defined as the first date for a claim associated with an opioid abuse ICD-9-CM code that satisfies the above enrollment requirements.

TABLE 2 Comparison of Prevalence Rates of Selected Comorbidities 1998-2002 (Patients Aged 12-64 Years)

\begin{tabular}{|c|c|c|c|c|c|c|}
\hline \multirow[b]{3}{*}{ Comorbidities $\dagger$} & \multicolumn{2}{|c|}{$\begin{array}{l}\text { Opioid Abusers } \\
(\mathrm{N}=740)\end{array}$} & \multicolumn{2}{|c|}{$\begin{array}{c}\text { Nonabusers } \\
(\mathrm{N}=2,220)\end{array}$} & \multirow{2}{*}{$\begin{array}{c}\text { Relative } \\
\text { Risk Ratio }\end{array}$} & \multirow{2}{*}{$\begin{array}{c}P \\
\text { Value* }^{*}\end{array}$} \\
\hline & $\mathrm{N}$ & $\%$ & $\mathrm{~N}$ & $\%$ & & \\
\hline & [A] & [B] & {$[C]$} & [D] & $\begin{array}{c}{[\mathrm{E}]=} \\
{[\mathrm{B}] /[\mathrm{D}]}\end{array}$ & \\
\hline Nonopioid poisoning & 130 & 17.6 & 5 & 0.2 & 78.0 & $<0.01$ \\
\hline Hepatitis (A,B, and C) & 48 & 6.5 & 4 & 0.2 & 36.0 & $<0.01$ \\
\hline Other substance abuse & 373 & 50.4 & 26 & 1.2 & 43.0 & $<0.01$ \\
\hline Pancreatitis & 7 & 0.9 & 1 & 0.05 & 21.0 & $<0.01$ \\
\hline Psychiatric diagnoses & 526 & 71.1 & 186 & 8.4 & 8.5 & $<0.01$ \\
\hline $\begin{array}{l}\text { Cirrhosis/chronic or } \\
\text { acute liver disease }\end{array}$ & 33 & 4.5 & 13 & 0.6 & 7.6 & $<0.01$ \\
\hline $\begin{array}{l}\text { Motor vehicle traffic } \\
\text { accidents }\end{array}$ & 10 & 1.4 & 5 & 0.2 & 6.0 & $<0.01$ \\
\hline HIV/AIDS & 10 & 1.4 & 6 & 0.3 & 5.0 & $<0.01$ \\
\hline Hepatitis (E and Other) & 3 & 0.4 & 2 & 0.1 & 4.5 & 0.07 \\
\hline Skin infections/abscesses & 75 & 10.1 & 55 & 2.5 & 4.1 & $<0.01$ \\
\hline Burns & 6 & 0.8 & 6 & 0.3 & 3.0 & 0.05 \\
\hline Gastrointestinal bleeding & 59 & 8.0 & 57 & 2.6 & 3.1 & $<0.01$ \\
\hline Trauma & 270 & 36.5 & 333 & 15.0 & 2.4 & $<0.01$ \\
\hline Herpes simplex & 10 & 1.4 & 14 & 0.6 & 2.1 & 0.06 \\
\hline $\begin{array}{l}\text { Sexually transmitted } \\
\text { diseases }\end{array}$ & 59 & 8.0 & 96 & 4.3 & 1.8 & $<0.01$ \\
\hline Hepatitis (alcoholic) & 1 & 0.1 & 0 & 0.0 & - & - \\
\hline Endocarditis & 5 & 0.7 & 0 & 0.0 & - & - \\
\hline
\end{tabular}

* Chi-square tests were conducted to compare the prevalence rates of comorbidities for opioid abusers and nonabusers.

† For ICD-9-CM codes corresponding to each comorbidity group, see Appendix A. 


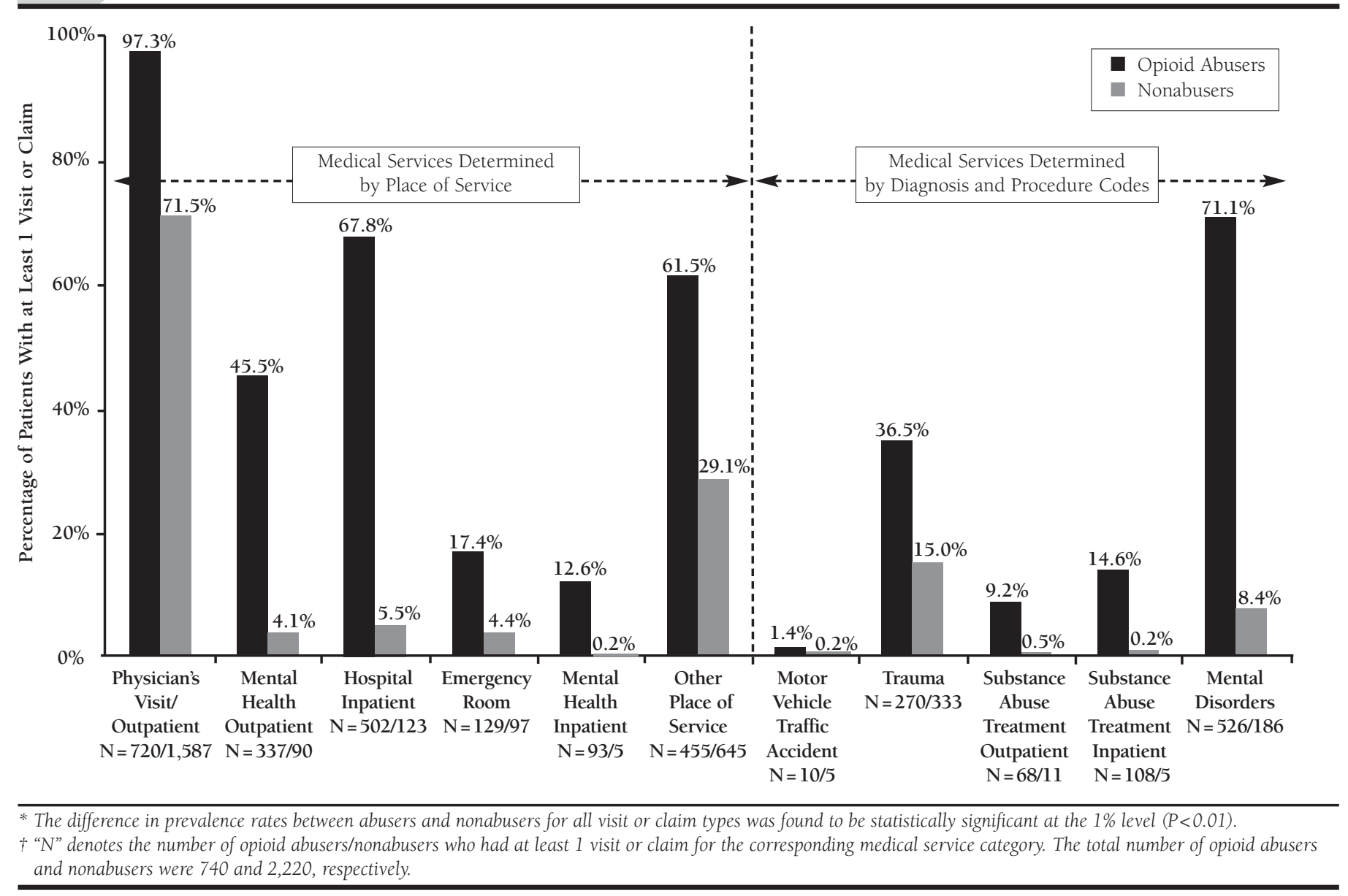

different stages of their abuse: onset, treatment, management, and/or recovery. In addition, the nature of opioid abuse and the fact that it likely lasts for several years with associated higher prevalence rates of certain comorbidities creates difficulties in identifying the beginning or end of abuse and the costs associated with it. Therefore, by taking a more general cross-sectional approach in calculating the average direct health care costs associated with opioid abuse, patients with varying degrees of severity and in different stages of their illnesses were captured. Thus, we selected patients on the basis of a claim for opioid abuse, conditioned on having their medical claims history for the 6 months preindex and postindex date.

\section{Calculation of Direct Costs}

Direct health care costs were calculated based on payments made by payers for inpatient, outpatient, physician, and prescription drug claims as well as for all other medical services. Since the focus of this study was on the payer burden of opioid abuse, these payments did not include deductibles or copay- ments paid by the patients (i.e., the claim field used in the current study was net plan cost after subtraction of copayments and other member cost share). The dollar amounts for all claims for each patient during the 12 months including the 6-month preindex and 6-month postindex date were summed to arrive at their total direct medical costs. These costs were then averaged over all patients in the research samples to arrive at the average cost per patient for opioid abusers and nonabusers.

\section{Results}

The resulting sample sizes for the study were 740 opioid abusers and 2,220 nonabusers. Males accounted for 57\% of opioid abusers and nonabusers (Table 1). The average age of opioid abusers was 37.6 years, and $52.6 \%$ of opioid abusers were in the 35 to 54 -year age range.

The prevalence of opioid abuse among the members in our database increased from 5 per 10,000 in 1998 to 8 per 10,000 in 2002, where the denominator was the total annual number of insured members in each year, and the numerator was the 


\begin{tabular}{|c|c|c|c|c|c|c|c|c|c|c|c|}
\hline & \multicolumn{5}{|c|}{$\begin{array}{l}\text { Opioid Abusers } \\
\quad(\mathrm{N}=740)\end{array}$} & \multicolumn{5}{|c|}{$\begin{array}{l}\text { Nonabusers } \\
(\mathrm{N}=2,220)\end{array}$} & \multirow{4}{*}{\begin{tabular}{|c}
$\begin{array}{c}\text { Relative Risk } \\
\text { Ratio }\end{array}$ \\
{$[\mathrm{C}]=$} \\
{$[\mathrm{A}] /[\mathrm{B}]$}
\end{tabular}} \\
\hline & \multirow{2}{*}{\multicolumn{2}{|c|}{$\begin{array}{c}\text { Number }(\%) \\
\text { of Patients } \\
\text { With at Least } 1 \text { Claim }\end{array}$}} & \multicolumn{3}{|c|}{ Number of Claims per Patient } & \multirow{2}{*}{\multicolumn{2}{|c|}{$\begin{array}{l}\text { Number (\%) } \\
\text { of Patients } \\
\text { th at Least } 1 \text { Claim }\end{array}$}} & \multicolumn{3}{|c|}{ Number of Claims per Patient } & \\
\hline & & & Mean* & SD & Median & & & Mean* & SD & Median & \\
\hline & & [A] & & & & & {$[\mathrm{B}]$} & & & & \\
\hline $\begin{array}{l}\text { Prescription drugs } \\
\text { All prescription drugs } \\
\text { All nonopioids }\end{array}$ & $\begin{array}{l}643 \\
637\end{array}$ & $\begin{array}{l}86.9 \% \\
86.1 \%\end{array}$ & $\begin{array}{l}41.6^{\mathrm{a}} \\
32.4^{\mathrm{a}}\end{array}$ & $\begin{array}{l}41.9 \\
32.7\end{array}$ & $\begin{array}{l}27.0 \\
23.0\end{array}$ & $\begin{array}{l}1,369 \\
1,353\end{array}$ & $\begin{array}{l}61.7 \% \\
60.9 \%\end{array}$ & $\begin{array}{l}13.8^{\mathrm{a}} \\
13.0^{\mathrm{a}}\end{array}$ & $\begin{array}{l}19.3 \\
17.5\end{array}$ & $\begin{array}{l}7.0 \\
7.0\end{array}$ & $\begin{array}{l}1.4^{\mathrm{a}} \\
1.4^{\mathrm{a}}\end{array}$ \\
\hline $\begin{array}{l}\text { Prescription opioids } \\
\text { SAOs } ¥ \text { only } \\
\text { LAOs§ only } \\
\text { Both SAOs and LAOs }\end{array}$ & $\begin{array}{r}304 \\
7 \\
127\end{array}$ & $\begin{array}{r}41.1 \% \\
0.9 \% \\
17.2 \%\end{array}$ & $\begin{array}{r}9.4^{\mathrm{a}} \\
6.9 \\
25.7\end{array}$ & $\begin{array}{r}11.9 \\
5.6 \\
15.5\end{array}$ & $\begin{array}{r}4.0 \\
9.0 \\
24.0\end{array}$ & $\begin{array}{r}421 \\
3 \\
8\end{array}$ & $\begin{array}{r}19.0 \% \\
0.1 \% \\
0.4 \%\end{array}$ & $\begin{array}{r}2.3^{\mathrm{a}} \\
11.3 \\
32.1\end{array}$ & $\begin{array}{r}3.6 \\
14.6 \\
32.4\end{array}$ & $\begin{array}{r}1.0 \\
5.0 \\
23.0\end{array}$ & $\begin{array}{r}2.2^{\mathrm{a}} \\
7.0^{\mathrm{a}} \\
47.6^{\mathrm{a}}\end{array}$ \\
\hline \multicolumn{12}{|c|}{ 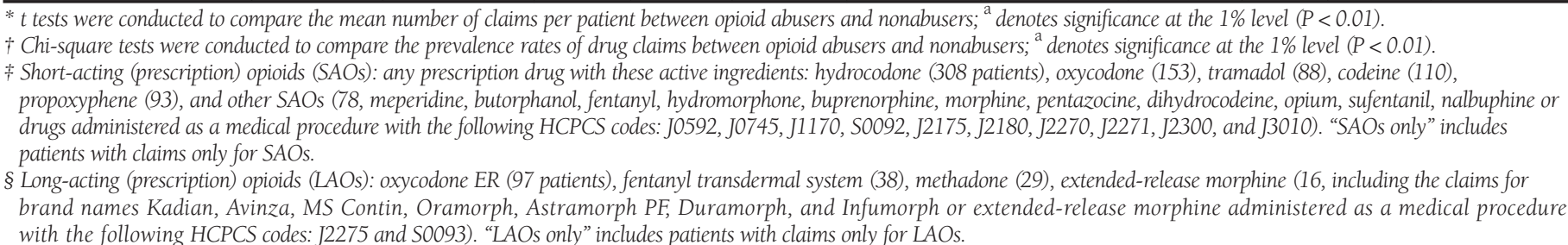 } \\
\hline
\end{tabular}

of such visits for opioid abusers were more than 5 times higher compared with nonabusers ( $\$ 5,000$ vs. $\$ 906, P<0.01$ ). Average drug costs for opioid abusers were more than 5 times higher compared with those for nonabusers (\$2,034 vs. \$386), while such drug costs accounted for $21 \%$ of overall costs for nonabusers compared with $13 \%$ for opioid abusers.

We also conducted sensitivity analyses on direct health care costs based on different groupings of the ICD-9-CM codes. In particular we divided our sample into 2 subgroups: one based on ICD-9-CM codes 304.7 and 305.5, codes for "abuse" ("Group A," $\mathrm{N}=141$ ), and another based on the ICD-9-CM codes 304.0 and 965.0, codes for "dependence" and "poisoning" (excluding 965.01, "Group B," $\mathrm{N}=635$ ). The subgroups are not mutually exclusive since it is possible for a patient to be diagnosed with more than one ICD-9-CM code for opioid abuse. Using the same methodology as above, the total average per-patient direct health care payer cost for Group A was $\$ 18,388$ compared with $\$ 2,210$ for matched controls $(P<0.01)$. For Group B, the total average per-patient direct health care cost was $\$ 16,204$ compared with $\$ 2,179$ for matched controls $(P<0.01)$. In both instances, the direct health care costs of Groups A and B were approximately 8 times as high as the matched controls, consistent with the findings above for the broader group used for this study. It appears that Group A has costs that are higher than Group B, indicating that those patients diagnosed as opioid "abusers" have higher costs than those diagnosed as opioid "dependent." This finding should be interpreted with caution given the different uses of the term opioid abuse. Thus, the range of cost estimates for our sample of opioid abusers based on alternative groupings of ICD-9-CM codes is $\$ 15,884$ to $\$ 18,388$, and $\$ 1,830$ to $\$ 2,210$ for our matched sample.

The descriptive analyses reported above do not control for comorbidities. The methodology adopted here considers direct health care costs for opioid abusers arising from the presence of other comorbid conditions such as pancreatitis, hepatitis, etc., in addition to opioid abuse-related costs. Analysis using a multivariate regression approach (described below) would allow for a more direct comparison of costs between opioid abusers and a matched control while simultaneously controlling for a variety of factors such as comorbidity profiles and demographics that may drive costs. Furthermore, it would be useful to have an alternative benchmark control group with which to compare the costs of opioid abuse; for this purpose, we have chosen a control group of patients with a diagnosis of depression (ICD-9-CM codes 296.2, 296.3, 300.4, 309.0, 309.1, and 311).

Depression is a mental health illness that is common and is diagnosed on a relatively consistent basis. Similar to opioid abuse, this condition is managed by primary care doctors and specialists and is also a costly condition of interest to payers. ${ }^{15}$ This regression allows us to compare the costs of an opioid abuser to those of a depressed patient, holding other factors constant, such as age, gender, and the presence of other comorbid conditions. This allows for a more direct and meaningful comparison of the costs associated with opioid abuse.

We constructed a multivariate regression to account for this, where the left-hand variable was the per-patient costs during the 12-month period encompassing the 6 months preindex and 
6 months postindex date. Patients were matched on a 3:1 basis (as before), and overlap between the 2 groups was controlled for (e.g., patients who had a diagnosis of both depression and opioid abuse). The regression specification is as below:

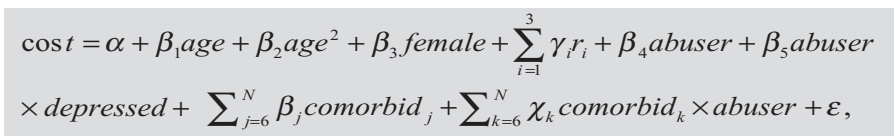

where female is a dummy variable taking the value 1 if the patient is female, 0 otherwise; $r_{i}$ is a dummy variable taking the value 1 if the patient is in region $i, 0$ otherwise; abuser is a dummy variable taking the value 1 if the patient is an opioid abuser, 0 otherwise; abuser $x$ depressed is an interaction term taking the value of 1 if the patient has at least 1 diagnosis for opioid abuse and at least 1 diagnosis for depression, 0 otherwise; and comorbid ${ }_{j}$ are dummy variables taking the value 1 if the patient has a given comorbid condition, 0 otherwise. The variables

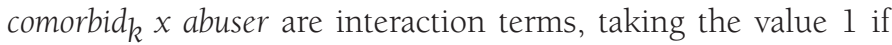
the patient is an opioid abuser and has a given comorbid condition; $\varepsilon$ is the error term.

When we calculated descriptive statistics for our 2 samples, we found that the per-patient costs of opioid abuse were 3.4 times higher than the matched control of depressed patients, $\$ 16,722$ for opioid abusers compared with $\$ 4,875$ for depressed patients. Based on the regression results that control for the effects of comorbid conditions, we found that the incremental costs of opioid abuse relative to depressed patients was $\$ 3,040$, indicating that opioid abusers were 1.8 times as costly as depressed patients ( $\$ 3,040$ vs. $\$ 3,619)$ (Table 5). The coefficient estimates on the comorbidities included in the regression indicated that the incremental costs of the comorbidities (i.e., the additional costs compared with patients without the comorbid condition) of other substance abuse, psychiatric diagnoses, and trauma, were $\$ 5,169, \$ 2,677$, and $\$ 3,145$, respectively. The results suggested that patients who were abusers and had a psychiatric diagnosis or a trauma incident had additional psychiatric or trauma costs of $\$ 2,025$ and $\$ 2,066$, respectively. That is, psychiatric costs were $\$ 4,702$ (i.e., $\$ 2,677+\$ 2,025$ ) and $\$ 5,211$ (i.e., $\$ 3,145+$ $\$ 2,066$ ) for opioid abusers compared with those without that comorbid condition.

\section{Discussion}

The analyses presented here highlight the substantial payer burden associated with patients who are diagnosed as opioid abusers. We are not aware of any other studies that have systematically quantified and compared the direct medical and drug costs of opioid abusers with a cohort of nonabusers. This group of opioid abusers has direct health care costs that are more than 8 times higher than those of nonabusers. These cost measures were the total per-patient direct health care costs and included costs associated with other comorbid conditions. Even when one controls for comorbidities using a multivariate regression analysis, we found that opioid abusers were 1.8 times as costly to the payer as a matched control of depressed patients. In fact, much of the cost of opioid abuse is driven by such things as hospitalizations and emergency room visits. This analysis has shown that opioid abusers have higher prevalence rates of certain comorbidities (such as nonopioid poisoning, hepatitis $[A, B, C]$, pancreatitis, etc.) and have higher utilization rates of medical services such as hospital inpatient visits. This suggests that these factors may have jointly contributed to the higher level of per-patient costs associated with opioid abusers compared with nonabusers.

\section{Limitations}

Focusing only on the direct health care costs understates the full cost burden imposed by indirect costs associated with disability, absenteeism, and presenteeism (defined as the feeling that one must go to work even if one is too ill to be productive or effective). It is important for payers to consider indirect costs in calculating the true overall burden of opioid abuse. Birnbaum et al. note that lost productivity costs accounted for $50 \%$ of the societal cost of prescription opioid abuse in the United States in 2001.12

Since the diagnosis codes in medical claims do not distinguish between prescription and nonprescription opioid abuse, it was not possible in this study to examine the relationship of nonmedical use of nonprescription (e.g., heroin, cocaine, etc.) drugs to prescription opioid (e.g., morphine, hydrocodone, etc.) and total direct health care costs. Since $58 \%$ of opioid abusers had claims for SAOs, LAOs, or both, $42 \%$ of opioid abusers (as defined here) may be abusing other prescription drugs or nonprescription (illicit) narcotics. Further research should seek to distinguish between abuse of prescription narcotics and illicit narcotics and measure indirect costs as well as direct costs for prescription and illicit opioids.

A more thorough analysis of the comorbidity profile of opioid abuse patients, including an assessment of the temporal pattern of such comorbidities, would be valuable in understanding cost drivers. For example, if the onset of opioid abuse is associated with human immunodeficiency virus (HIV) or hepatitis (A, B, or C), then a cost offset may be realized by advocating better treatment of opioid abuse; however, longitudinal examinations of temporal patterns may not be possible in administrative claims databases due to relatively limited duration of membership of opioid abusers.

Future research with Medicaid data is also necessary to shed light on the prevalence and costs of opioid abuse among a Medicaid population and possibly to help understand more clearly the causal relationship between opioid abuse and the comorbidities discussed here. The costs of such patients in a Medicaid population could be quite different compared with those reported here from commercial health plan members. It would also be useful to extend the multivariate regression 
(FIGURE 2 Average Annual Direct Costs* of Opioid Abusers and Nonabusers, 1998-2002

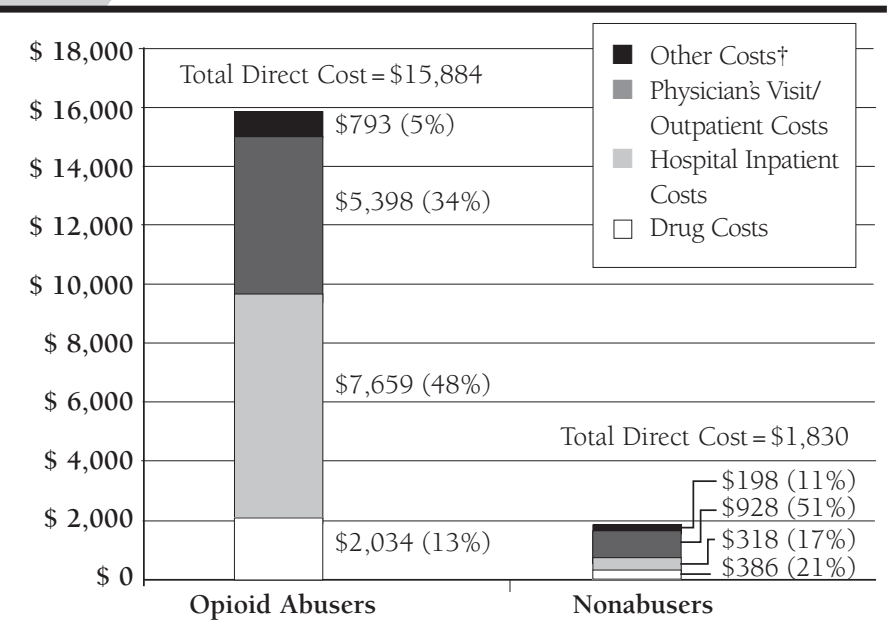

* Costs are in 2003 dollars. The differences between all mean annual costs of opioid abusers and nonabusers are statistically significantly different at the $1 \%$ level $(P<0.01)$ except for "Other Costs" for which the "Other Place of Service" component is significantly different at the $5 \%$ level $(P<0.05)$.

† "Other Costs" include: "Other Place of Service" and "Emergency Room" costs.

\section{TABLE $5 \longdiv { \text { Regression Results } }$}

\begin{tabular}{|c|c|c|c|}
\hline & $\begin{array}{l}\text { Parameter } \\
\text { Estimate }\end{array}$ & $\begin{array}{c}\text { Standard } \\
\text { Error }\end{array}$ & $P$ Value \\
\hline Intercept & 3,619 & 2,258 & 0.1090 \\
\hline $\begin{array}{l}\text { Demographics } \\
\text { Age } \\
\text { Age squared } \\
\text { Gender }(\text { female }=1)\end{array}$ & $\begin{array}{r}-188 \\
4 \\
568\end{array}$ & $\begin{array}{r}121 \\
2 \\
582\end{array}$ & $\begin{array}{l}0.1213 \\
0.0121 \\
0.3293\end{array}$ \\
\hline $\begin{array}{l}\text { Regions (reference = Region } 4 \text { - West) } \\
\text { Region } 1 \text { - Northeast } \\
\text { Region } 2 \text { - Midwest } \\
\text { Region } 3 \text { - South }\end{array}$ & $\begin{array}{r}75 \\
-459 \\
-1,421\end{array}$ & $\begin{array}{r}1,021 \\
1,098 \\
889\end{array}$ & $\begin{array}{l}0.9411 \\
0.6760 \\
0.1099\end{array}$ \\
\hline $\begin{array}{l}\text { Comorbidities (reference }=\text { none }) \\
\text { Other substance abuse } \\
\text { Psychiatric diagnoses } \\
\text { Trauma }\end{array}$ & $\begin{array}{l}5,169 \\
2,677 \\
3,145\end{array}$ & $\begin{array}{r}1,333 \\
664 \\
743\end{array}$ & $\begin{aligned} & 0.0001 \\
&<0.0001 \\
&<0.0001\end{aligned}$ \\
\hline $\begin{array}{l}\text { Interaction terms for comorbidities } \\
\text { Other substance abuse x abuser } \\
\text { Psychiatric diagnoses } \mathrm{x} \text { abuser } \\
\text { Trauma x abuser }\end{array}$ & $\begin{array}{r}1 \\
2,025 \\
2,066\end{array}$ & $\begin{array}{l}1,752 \\
1,371 \\
1,408\end{array}$ & $\begin{array}{l}0.9996 \\
0.1397 \\
0.1425\end{array}$ \\
\hline Abuser (reference= depressed patient) & 3,040 & 1,217 & 0.0125 \\
\hline Abuser $\mathrm{x}$ depressed patient & 6,452 & 1,213 & $<0.0001$ \\
\hline $\begin{array}{l}\text { Adjusted } r \text {-squared }=0.1612 \text {. } \\
\text { Number of observations }=2,880 . \\
\text { Dependent variable }=\text { direct health care cos }\end{array}$ & & & \\
\hline
\end{tabular}

analysis to account for additional factors that may drive costs, including duration of abuse, prior medical history, and the presence of multiple substance abuse treatments.

As was noted earlier, the concept of opioid abuse is often interpreted differently by different people. Given the possibility for miscoding with ICD-9-CM codes ${ }^{16}$ we attempted to include all ICD-9-CM codes that related to opioid abuse, recognizing the possibility that those codes may not always capture the phenomenon of opioid abuse.

\section{Conclusion}

Opioid abuse is a costly condition that imposes a large direct cost burden on private payers. Opioid abusers have direct health care costs that are approximately 8 times higher than those of nonabusers. These costs are likely driven by higher prevalence rates of costly comorbidities.

\section{ACKNOWLEDGMENTS}

The authors gratefully acknowledge helpful comments and insights on this paper from Vanja Sikirica, PharmD, manager, primary care outcomes research, and Dilesh Doshi, PharmD, associate director, regional outcomes research, Janssen Medical Affairs, L.L.C., Raritan, NJ, and San Diego, CA, respectively.

\section{DISCLOSURES}

Funding for this research was provided by an unrestricted grant from Janssen Medical Affairs, L.L.C. and was obtained by authors Susan Vallow and Jeff Schein, who are employed by Janssen Medical Affairs, L.L.C. Nathaniel Katz is a consultant to Janssen and numerous other pharmaceutical companies that manufacture branded opioid products and nonopioid analgesics; authors Alan G. White, Howard G. Birnbaum, Milena N. Mareva, and Maham Daher disclose no potential bias or conflict of interest relating to this article.

White served as principal author of the study. Study concept and design were contributed primarily by White, Vallow, Schein, and Katz. Analysis and interpretation of data were contributed by all authors. Drafting of the manuscript was primarily the work of White, and its critical revision was the work of White and Vallow. Statistical expertise was contributed by White, Birnbaum, and Daher, and administrative, technical, and/or material support was provided by Analysis Group, Inc., Boston, MA.

\section{REFERENCES}

1. Virag T, Packer LE, Davis TR, et al. 1998 National Household Survey on Drug Abuse: Summary Tables. Prevalence Estimates, Standard Errors, and $P$ Values. Vols. $1 \& 2$. Rockville, MD: Substance Abuse and Mental Health Services Administration, Office of Applied Studies; August 1999. Available at: http://www.oas.samhsa.gov/NHSDA/98DetailedTables/sumtab98.pdf. Accessed May 12, 2004

2. Chromy JR, Davis TR, Emrich SL, et al. 2000 National Household Survey on Drug Abuse: Detailed Tables. Rockville, MD: Substance Abuse and Mental Health Services Administration, Office of Applied Studies; March 2002. Available at: http://www.oas.samhsa.gov/NHSDA/2kdetailedtabs/ pdf/2kNHSDAtables-pdf.htm. Accessed May 12, 2004

3. Barnett K, Bowman KR, Brown JM, et al. Results from the 2001 National Household Survey on Drug Abuse: Volume III: Detailed Tables. Rockville, MD: Substance Abuse and Mental Health Services Administration, Office of Applied Studies; September 2002. Available at: http://www.oas.samhsa.gov/ nhsda/2klnhsda/vol3/frontMatter_W.pdf. Accessed May 12, 2004.

4. Substance Abuse and Mental Health Services Administration. Overview of findings from the 2003 National Survey on Drug Use and Health. Rockville, MD: Substance Abuse and Mental Health Services Administration. Office of Applied Studies; September 2004. NSDUH Series H-24, DHHS Publication no. SMA 04-3963. 
5. Treatment Episode Data Set (TEDS) Quick Statistics—Summary Tables, 19922003: Admissions Level Data. Rockville, MD: Substance Abuse and Mental Health Services Administration, Office of Applied Studies. Available at: http://wwwdasis.samhsa.gov/webt/ tedsweb/tab_year.choose_year?t_state=US Accessed June 20, 2005.

6. Ball J, Garfield T, et al. Emergency Department Trends from the Drug Abuse Warning Network, Preliminary Estimates January-June 2002. Rockville, MD: Substance Abuse and Mental Health Services Administration. Office of Applied Studies; December 2002. DAWN Series: D-22, DHHS Publication no. (SMA) 03-3779.

7. Zacny J, Bigelow G, Compton P, Foley K, Iguchi M, Sannerud C. Position statement of the College on Problems of Drug Dependence taskforce on prescription opioid non-medical use and abuse. Drug Alcohol Depend. 2003;69(3):215-32.

8. Harwood H, Fountain D, Livermore G. The Economic Costs of Alcohol and Drug Abuse in the United States-1992. Rockville, MD: National Institutes of Health, National Institute on Drug Abuse; September 1998. NIH Publication no. 98-4327.

9. Harwood H, Bouchery E. The Economic Costs of Drug Abuse in the United States, 1992-1998. Washington, DC: Office of National Drug Control Policy (2001), Executive Office of the President; September 2001. Publication no. NCJ-190636.
10. French MT, Martin RF. The costs of drug abuse consequences: a summary of research findings. J Subst Abuse Treat. November-December 1996;13(6):453-66.

11. Mark TL, Woody GE, Juday T, Kleber HD. The economic cost of heroin addiction in the United States. Drug Alcohol Depend. 2001;61(2):195-206.

12. Birnbaum HG, Reynolds JR, Greenberg P, Zhang M, Vallow S, Schein JR. Costs of prescription opioid analgesic abuse in the United States in 2001: a societal perspective [manuscript under review]. Poster presented at: 2004 ACE Annual Meeting; September 11-14, 2004; Boston, MA

13. Public Policy of the ASAM: Definitions related to the use of opioids in pain treatment, American Academy of Pain Medicine, 2001. Available at http://www.asam.org/ppol/paindef.htm. Accessed April 21, 2005.

14. Jaminson RN, Kauffman J, Katz, N. Characteristics of methadone maintenance patients with chronic pain. J Pain Sympt Manage. 2000;19:53-62.

15. Greenberg PE, Kessler RC, Birnbaum HG, et al. Economic burden of depression in the United States: how did it change between 1990 and 2000? J Clin Psych. 2003;64(12):1465-75.

16. Curtiss FR. Evidence-based medicine: beware of results from randomized controlled trials and research with administrative claims data [editorial]. J Manag Care Pharm. 2005;11(2);172.

\section{Appendix A and Appendix B are on pages 478 and 479 , respectively.}




\section{APPENDIX A ICD-9-CM Diagnosis Codes Associated With Comorbid Conditions}

\begin{tabular}{|c|c|c|c|c|c|}
\hline Diagnosis Type & ICD-9-CM Codes & Diagnosis Description & Diagnosis Type & ICD-9-CM Codes & Diagnosis Description \\
\hline \multirow[t]{3}{*}{$\begin{array}{l}\text { Other substance } \\
\text { abuse } \\
\text { (excluding } \\
\text { opioid } 304.0, \\
\text { sedative abuse } \\
\text { 304.7and 305.5) }\end{array}$} & \multirow{3}{*}{\begin{tabular}{|l|}
$303 . X X$ \\
$304.1 X$ \\
$304.2 X$ \\
$304.3 X$ \\
$304.4 X$ \\
$304.5 X$ \\
$304.6 X$ \\
$304.8 X$ \\
$304.9 X$ \\
$305.0 X$ \\
$305.1 X$ \\
$305.2 X$ \\
$305.3 X$ \\
$305.4 X$ \\
$305.6 X$ \\
$305.7 X$ \\
$305.8 X$ \\
$305.9 X$ \\
V11.3 \\
\end{tabular}} & \multirow{3}{*}{$\begin{array}{l}\text { Alcohol dependance syndrome } \\
\text { Barbiturate and similarly acting or hypnotic } \\
\text { dependance } \\
\text { Cocaine dependance } \\
\text { Cannabis dependance } \\
\text { Amphetamine and other psychostimulant dependance } \\
\text { Hallucinogen dependance } \\
\text { Other specific drug dependance } \\
\text { Combinations of drug dependance excluding opioid } \\
\text { Unspecified drug dependance } \\
\text { Alcohol abuse } \\
\text { Tobacco dependance } \\
\text { Cannabis abuse } \\
\text { Hallucinogen abuse } \\
\text { Barbiturate and similarly acting sedative or } \\
\text { hypnotic abuse } \\
\text { Cocaine abuse } \\
\text { Amphetamine and other psychostimulant abuse } \\
\text { Antidepressant type abuse } \\
\text { Other, mixed, or unspecified drug abuse } \\
\text { Personal history of alcoholism }\end{array}$} & & $\begin{array}{l}070.41 \\
070.42 \\
070.44 \\
070.51 \\
070.52\end{array}$ & $\begin{array}{l}\text { Acute or unspecified hepatitis C with hepatic coma } \\
\text { Hepatitis delta without mention of active hepatitis B } \\
\text { disease with hepatic coma } \\
\text { Chronic hepatitis C with hepatic coma } \\
\text { Acute or unspecified hepatitis C without mention of } \\
\text { hepatic coma } \\
\text { Hepatitis delta without mention of active hepatitis B } \\
\text { disease or hepatic coma } \\
\text { Chronic hepatitis C without mention of hepatic coma } \\
\text { Hepatitis B carrier } \\
\text { Hepatitis C carrier }\end{array}$ \\
\hline & & & $\begin{array}{l}\text { Hepatitis } \\
\text { (alcoholic) }\end{array}$ & 571.1 & Acute alcoholic hepatitis \\
\hline & & & $\begin{array}{l}\text { Hepatitis } \\
\text { (E and other) }\end{array}$ & $\begin{array}{l}070.43 \\
070.49 \\
070.53 \\
070.59 \\
070.6 \\
070.9\end{array}$ & $\begin{array}{l}\text { Hepatitis E with hepatic coma } \\
\text { Other specified viral hepatitis with hepatic coma } \\
\text { Hepatitis E without mention of hepatic coma } \\
\text { Other specified viral hepatitis without mention of } \\
\text { hepatic coma } \\
\text { Unspecified viral hepatitis with hepatic coma } \\
\text { Unspecified viral hepatitis without mention of }\end{array}$ \\
\hline \multirow[t]{3}{*}{$\begin{array}{r}\text { Psychiatric } \\
\text { diagnoses }\end{array}$} & \multirow{3}{*}{$\begin{array}{l}290 . X X-302 . X X \\
306 . X X-319 . X X \\
\text { V11.X } \\
\text { (excluding V11.3) }\end{array}$} & \multirow{3}{*}{$\begin{array}{l}\text { Psychoses, neurotic disorders \& personality } \\
\text { disorders, and other nonpsychotic mental conditions } \\
\text { Neurotic and personality disorders, and other } \\
\text { nonpsychotic mental conditions, mental retardation } \\
\text { Personal history of mental disorder }\end{array}$} & & $\begin{array}{l}\text { V02.60 } \\
\text { V02.69 } \\
\end{array}$ & $\begin{array}{l}\text { hepatic coma } \\
\text { Viral hepatitis } \\
\text { Other viral hepatitis carrier }\end{array}$ \\
\hline & & & $\underline{\text { Pancreatitis }}$ & 577.XX & Diseases of the pancreas \\
\hline & & & \multirow{4}{*}{$\begin{array}{l}\text { Sexually } \\
\text { transmitted } \\
\text { diseases }\end{array}$} & \multirow{4}{*}{$\begin{array}{l}090 . X X-099 . X X \\
112.1 X \\
112.2 X \\
483.1 X \\
078.19 \\
078.11 \\
V 02.7 \\
\text { V02.8 } \\
647.0 \\
647.1 \\
647.2 \\
614-616 \\
131.00 \\
131.01 \\
131.02 \\
131.03 \\
131.09 \\
622.1 X \\
623.0 X\end{array}$} & \multirow{4}{*}{$\begin{array}{l}\text { Syphilis and other venereal diseases } \\
\text { Candidiasis of vulva and vagina } \\
\text { Candidiasis of other urogenital sites } \\
\text { Chlamydia } \\
\text { Other genital warts } \\
\text { Genital warts: condyloma acuminatum } \\
\text { Personal history of gonorrhea } \\
\text { Personal history of other venereal diseases } \\
\text { Syphilis } \\
\text { Gonorrhea carried by the mother during pregnancy } \\
\text { Other venereal diseases carried by the mother during } \\
\text { pregnancy } \\
\text { Inflammatory diseases of the female pelvic organs } \\
\text { Urogenital trichomoniasis, unspecified } \\
\text { Trichomonal vulvovaginitis } \\
\text { Trichomonal urethritis } \\
\text { Trichomonal prostatitis } \\
\text { Other trichomoniasis } \\
\text { Dysplasia of cervix } \\
\text { Dysplasia of vagina }\end{array}$} \\
\hline HIV/AIDS & $\begin{array}{l}042 . \mathrm{XX} \\
79.53 \\
\text { V08.X } \\
795.71 \\
\end{array}$ & $\begin{array}{l}\text { HIV disease } \\
\text { HIV virus type } 2 \\
\text { Asymptomatic HIV infection status } \\
\text { Nonspecific serologic evidence of HIV }\end{array}$ & & & \\
\hline Endocarditis & $\begin{array}{l}391.1 X \\
036.42 \\
074.22 \\
093.2 X \\
098.84 \\
112.81\end{array}$ & $\begin{array}{l}\text { Acute and subacute endocarditis } \\
\text { Endocarditis, valve unspecified } \\
\text { Endocarditis, valve unspecified, unspecified cause } \\
\text { Endocarditis in diseases classified elsewhere } \\
\text { Other-any condition classifiable to } 424.90 \text { with } \\
\text { specified cause, except rheumatic } \\
\text { Acute rheumatic endocarditis } \\
\text { Meningococcal endocarditis } \\
\text { Coxsackie endocarditis } \\
\text { Syphilitic endocarditis } \\
\text { Gonococcal endocarditis } \\
\text { Candidal endocarditis }\end{array}$ & & & \\
\hline \multirow{4}{*}{$\begin{array}{l}\text { Skin infections } \\
\text { /abscesses }\end{array}$} & \multirow{4}{*}{$\begin{array}{l}680-686 \\
681 . X X \\
693 . X X \\
693.8 X \\
693.9 X \\
111.8 X \\
111.9 X \\
707.9 X \\
\end{array}$} & \multirow{4}{*}{$\begin{array}{l}\text { Infections of skin and subcutaneous tissue } \\
\text { Cellulitis and abscess of finger and toe } \\
\text { Due to drugs and medicines } \\
\text { Due to other specified substances taken internally } \\
\text { Due to unspecified substance taken internally } \\
\text { Other specified dermatomycoses } \\
\text { Dermatomycosis, unspecified } \\
\text { Chronic ulcer of unspecified site }\end{array}$} & & & \\
\hline & & & $\underline{\text { Herpes simplex }}$ & 054 & Herpes simplex \\
\hline & & & Burns & 940.XX-949.XX & \\
\hline & & & \multirow{3}{*}{$\begin{array}{l}\text { Trauma } \\
\text { (excluding } \\
\text { motor } \\
\text { vehicle traffic } \\
\text { accidents) }\end{array}$} & \multirow{3}{*}{$\begin{array}{l}800-829 \\
830-839 \\
840-848 \\
850-854 \\
860-869 \\
870-879 \\
880-887 \\
890-897 \\
900-904 \\
905-909 \\
910-919 \\
920-924 \\
925-929 \\
930-939 \\
950-957 \\
958-959\end{array}$} & \multirow{3}{*}{$\begin{array}{l}\text { Fractures } \\
\text { Dislocation } \\
\text { Sprains and strains of joints and adjacent muscles } \\
\text { Intracranial injury, excluding those with skull fracture } \\
\text { Internal injury of thorax, abdomen, and pelvis } \\
\text { Open wound of head, neck, and trunk } \\
\text { Open wound of upper limb } \\
\text { Open wound of lower limb } \\
\text { Injury to blood vessels } \\
\text { Late effects of injuries, poisonings, toxic effects, and } \\
\text { other external causes } \\
\text { Superficial injury } \\
\text { Contusion with intact skin surface } \\
\text { Crushing injury } \\
\text { Effects of foreign body entering through orifice } \\
\text { Injury to nerves and spinal cord } \\
\text { Certain traumatic complications and unspecified } \\
\text { injuries }\end{array}$} \\
\hline GI bleeding & \begin{tabular}{|l}
$578 . X X$ \\
$456 . X X$ \\
$530.8 X$ \\
$531 . X X$ \\
$531.2 X$ \\
$532 . X X$ \\
$532.2 X$ \\
$533 . X X$ \\
$533.2 X$ \\
$534 . X X$ \\
$534.2 X$
\end{tabular} & $\begin{array}{l}\text { Gastrointestinal hemorrhage } \\
\text { Esophageal varices with bleeding } \\
\text { Other specified disorders of esophagus } \\
\text { Gastric ulcer-acute with hemorrhage } \\
\text { Gastric ulcer-acute with hemorrhage and perforation } \\
\text { Duodenal ulcer-acute with hemorrhage } \\
\text { Duodenal ulcer-acute with hemorrhage and perforation } \\
\text { Peptic ulcer-acute with hemorrhage } \\
\text { Peptic ulcer-acute with hemorrhage and perforation } \\
\text { Gastrojejunal ulcer-acute with hemorrhage } \\
\text { Gastrojejunal ulcer-acute with hemorrhage and } \\
\text { perforation }\end{array}$ & & & \\
\hline \multirow{3}{*}{$\begin{array}{l}\text { Cirrhosis/chronic } \\
\text { or acute liver } \\
\text { disease }\end{array}$} & \multirow{3}{*}{\begin{tabular}{|l|}
$570 . X X$ \\
$571 . X X$ \\
(excluding 571.1) \\
572.XX \\
573.XX \\
\end{tabular}} & \multirow{3}{*}{$\begin{array}{l}\text { Acute and subacute necrosis of liver } \\
\text { Chronic liver disease and cirrhosis } \\
\text { Liver abscess and sequelae of chronic liver disease } \\
\text { Other disorders of liver }\end{array}$} & & & \\
\hline & & & $\begin{array}{l}\text { Motor vehicle } \\
\text { traffic accidents }\end{array}$ & E810-E819 & \\
\hline & & & \multirow{2}{*}{$\begin{array}{l}\text { Poisoning } \\
\quad \text { (excluding } \\
\text { opioid abuse: } \\
\text { 965.00, 965.02 } \\
\text { and 965.09) }\end{array}$} & \multirow{2}{*}{$\begin{array}{l}\text { 960.XX-979.XX } \\
\text { 980.XX-989.XX }\end{array}$} & \multirow{2}{*}{$\begin{array}{l}\text { Poisoning by drugs, medicinal and biologic substances } \\
\text { Toxic effects of substances chiefly nonmedicinal as to } \\
\text { source }\end{array}$} \\
\hline Hepatitis $(A, B, C)$ & $\begin{array}{l}070.0 \\
070.1 \\
070.2 \mathrm{X} \\
070.3 \mathrm{X}\end{array}$ & $\begin{array}{l}\text { Viral hepatitis A with hepatic coma } \\
\text { Viral hepatitis A without mention of hepatic coma } \\
\text { Viral hepatitis B with hepatic coma } \\
\text { Viral hepatitis B without mention of hepatic coma }\end{array}$ & & & \\
\hline
\end{tabular}


(APPENDIX B Average Annual Direct Costs of Opioid Abusers and Nonabusers (1998-2002) (Patients Aged 12-64 Years) (2003 Dollars)

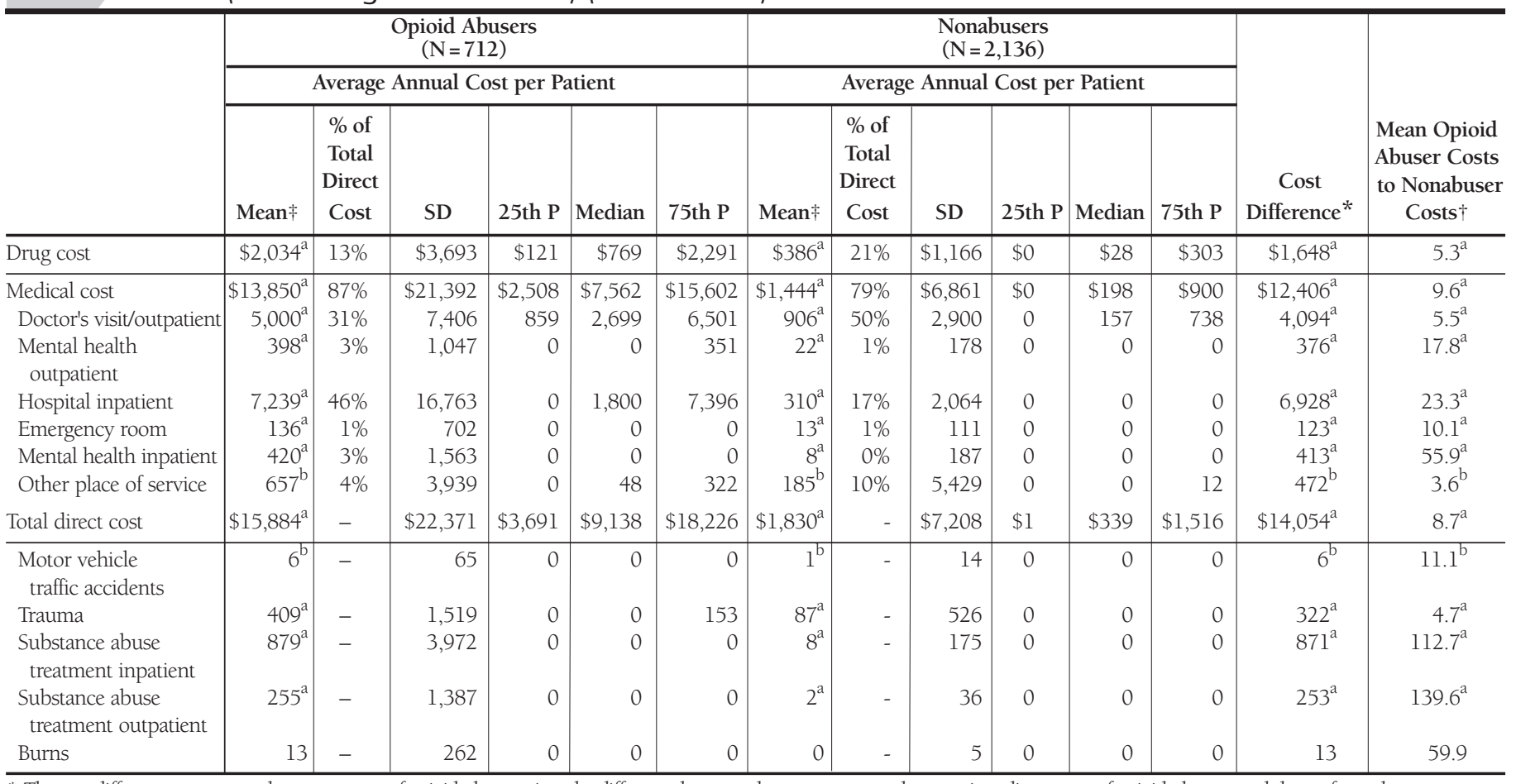

* The cost difference represents the excess costs of opioid abusers, i.e., the difference between the average annual per patient direct costs of opioid abusers and those of nonabusers.

+ The ratio of the costs of opioid abusers to those of nonabusers.

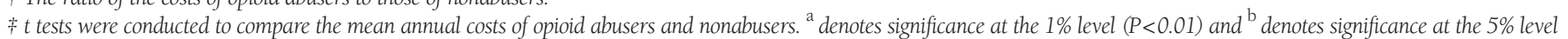
$(P<0.05)$. 